\title{
Charax goeldii Fowler, 1913 a valid species of Galeocharax Fowler (Characiformes: Characidae)
}

\author{
Naércio A. Menezes
}

Charax goeldii Fowler is resurrected from synonymy of Galeocharax gulo and redescribed. Its inclusion in Galeocharax is justified, and comments on the distribution of the species of this genus are made. The record of Galeocharax gulo in the rio São Francisco is considered a mistake.

Charax goeldii Fowler é retirada da sinonímia de Galeocharax gulo e redescrita. Sua inclusão em Galeocharax é discutida e são feitos comentários sobre a distribuição das espécies deste gênero. O registro de Galeocharax gulo no rio São Francisco é considerado um engano.

Key words: Freshwater fishes, South America, Brazil, rio Madeira, Taxonomy.

\section{Introduction}

Charax goeldii was originally described by Fowler (1913) based on a single specimen collected in a tributary of the rio Madeira near Porto Velho. Menezes (1976: 43-45) and Lucena \& Menezes (2003: 203) considered it synonymous with Galeocharax gulo (Cope). However, the examination of recently collected specimens in the rapids of rio Madeira in Porto Velho and of the holotype of Charax goeldii indicated that this species is distinct from Galeocharax gulo. Charax goeldii is resurrected from synonymy, its allocation into Galeocharax Fowler is discussed and the species redescribed.

\section{Material and Methods}

The specimens examined in this study are from the Museu de Zoologia, Universidade de São Paulo (MZUSP), Academy of Natural Sciences of Philadelphia (ANSP), and Universidade Federal de Rondônia (UNIR). The procedures for taking measurements and counts are according to Fink \& Weitzman (1974) and Menezes (2006). Vertebral counts were taken from radiographs and included the four vertebrae of the Weberian apparatus and the terminal "half centrum". In species description the range of meristic characters is presented first, followed in parentheses by counts of the holotype and the mean of the sample. All counts are based on the examination of 22 specimens, with exception of the number of vertebrae, counted in 15 specimens. Data pertaining to Galeocharax gulo (Cope), G. knerii (Steindachner), and G. humeralis (Valenciennes) are from Menezes (1976).
Results

\section{Galeocharax goeldii (Fowler, 1913)}

Figs. 1 and 2

Charax goeldii Fowler, 1913: 568 (type locality: Madeira River, about 200 miles east of longitude 60²0', Brazil; type examined; Schultz, 1950: 62 [as synonymous of Cyrtocharax amazonus (Günther)]; Géry, 1972: 27-28 (redescription of type); Menezes, 1976: 43 [as synonymous of Galeocharax gulo (Cope), based on Géry’s (1972: 72) data]; Böhlke, 1984: 47 (type catalog; possibly valid as Cynopotamus goeldii); Eschmeyer, 1998: 657 (catalog; as synonymous of Galeocharax gulo).

Cyrtocharax goeldii; Fowler, 1950: 311 (synonymy; distribution). Cynopotamus (Acestrocephalus) goeldii; Géry \& Vu-Tân-Tuê, 1963: 240 (diagnosis in key); Géry, 1972: 28-29 (taxonomic data; diagnosis in key).

Material examined. ANSP 39308, holotype, $44.3 \mathrm{~mm}$ SL, Brazil, Rondônia: tributary of rio Madeira near Porto Velho, Edgard A. Smith, January 1913. The following lots collected in Rondônia, rio Madeira between Guajará-Mirim and Porto Velho. MZUSP 92435, 3 of 4, 37 99 mm SL, igarapé Belmont, 8³8'27"S 6350'58"W; MZUSP 92436, 11 of $24,25.7-84.9 \mathrm{~mm}$ SL, igarapé Karipuna, $9^{\circ} 15^{\prime} 10^{\prime \prime S} 64^{\circ} 38^{\prime} 31^{\prime \prime W}$; MZUSP 92432, 2 of 5, 31-39 mm SL, igarapé Simão Grande, 9³2'36"S 65¹3'04"W; MZUSP 92433, 3 of 8, 44.5-49 mm SL, salto Jirau, 9¹9'43"S 6454'31"W; MZUSP 92434, 1, 109 mm SL, igarapé Jatuarana, 8³8'15"S 635'ㄱ' "W; UNIR 0008 1, 123 mm SL, igarapé do Arara, $10^{\circ} 0$ ' $45^{\prime \prime} \mathrm{S} 65^{\circ} 18^{\prime} 50^{\prime \prime} \mathrm{W}$. 


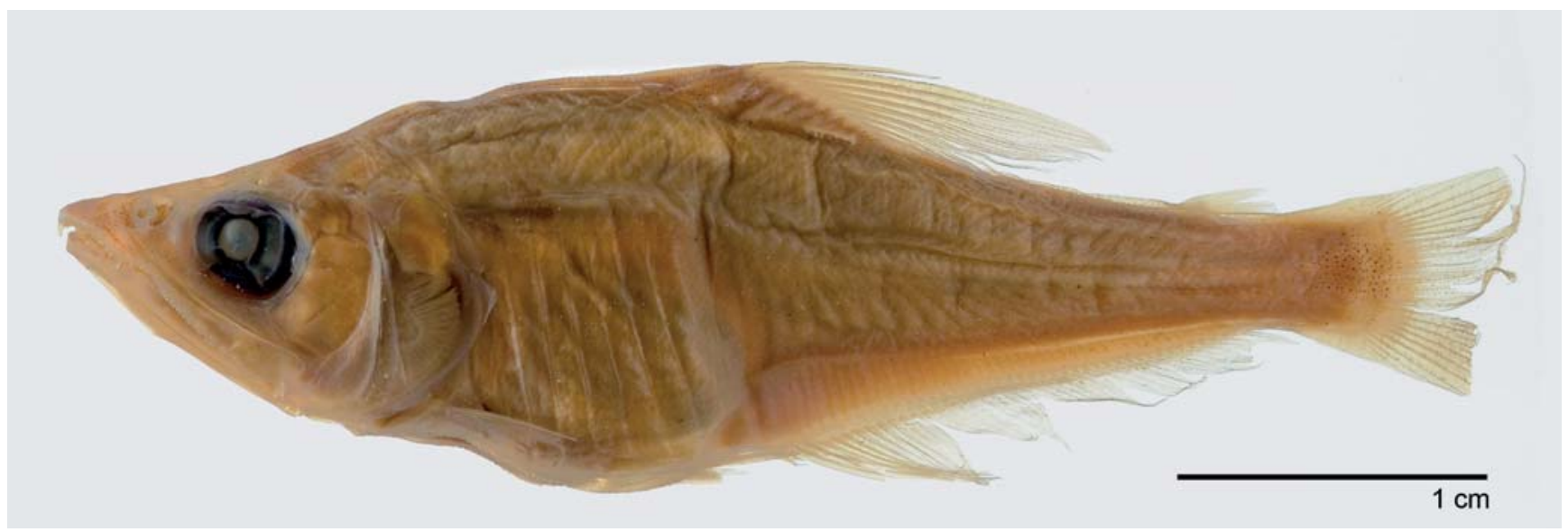

Fig. 1. Galeocharax goeldii, ANSP 39308, holotype, $44.3 \mathrm{~mm} \mathrm{SL}$, tributary of Madeira River near Porto Velho, Brazil.

Diagnosis. Among the species presently assigned to Galeocharax, G. goeldii is most similar to G. gulo and G. knerii with respect to most meristic characters, with exception of the number of perforated lateral line scales (87-95 in G. goeldii vs 80-86 in G. gulo and G. knerii). It differs from G. humeralis by having fewer perforated lateral line scales (87-95 vs 98-101 in G. humeralis), fewer horizontal scale rows from dorsal-fin origin to lateral line(17-18 vs 20-22 in G. humeralis) and fewer maxillary teeth (35-45 vs 47-52 in G. humeralis).

Description. Morphometrics of holotype and all specimens examined presented in Table 1. Body elongate, moderately large ( $\mathrm{SL}=31-123 \mathrm{~mm} \mathrm{SL}$ ), compressed and moderately deep; greatest body depth slightly in advance of dorsal-fin origin. Dorsal body profile straight from tip of snout to anterior part of fontanel, slightly concave from that point to base of supraoccipital spine, convex from that point to dorsal-fin origin, nearly straight along dorsal-fin base and from end of dorsalfin base to caudal peduncle. Ventral body profile convex all the way from tip of lower jaw to anal-fin origin, nearly straight along anal-fin base and slightly concave from end of anal-fin base to beginning of procurrent rays. Snout pointed. Lower jaw included in upper jaw when mouth is totally closed. Maxilla extending slightly beyond vertical crossing posterior border of orbit.

Dorsal-fin rays ii,9 in all specimens, posterior most ray unbranched. Adipose fin present. Anal-fin rays iv or v, usually iv unbranched, branched rays 40-44 (iv,41), 41.9. Weakly developed anterior anal-fin lobe including anterior unbranched rays and first 7-8 branched rays. One male specimen (MZUSP $92434,109 \mathrm{~mm} \mathrm{SL}$ ) with bilateral hooks on posterior anterior 18 branched rays, number of hooks varying considerably: first branched ray with 18 , fourth with 22 , eighth with 14 , tenth with 8 , fifteenth with 8 and eighteenth with 1 . Pectoral-fin rays $i, 14-17(i, 15), 15.5$. Posterior tips of longest pectoral-fin rays reaching slightly beyond pelvic-fin origin. Pelvic-fin rays i,7. No hooks on pelvic-fin rays of sexually mature males. Distal tips of longest pelvic-fin rays reaching slightly beyond anal-fin origin in specimens of 40-90 mm SL, but only to or slightly beyond posterior border of anus in specimens larger than $100 \mathrm{~mm}$ SL. Principal caudal-fin ray count $10 / 9$ in all specimens.

Lateral line complete, perforated scales 87-95 (87), 89.8. Horizontal scale rows above lateral line 17-19 (18), 17. Horizontal scale rows below lateral line 16-18 (18), 17.1. Scale rows around caudal peduncle 26-27 (26), 26.3. Three scale rows anteriorly along both sides of anal-fin base, reduced to one row posteriorly.

Premaxilla with two slightly enlarged inner conical teeth, an outer row with one anterior canine-like tooth followed by a row of 7-10 (10), 8.5 small conical teeth and another caninelike tooth. Anterior canine-like tooth outside anterior border of lower jaw when mouth closed. Maxillary teeth conical, highly variable in number, 35-46 (40), 39.5. Dentary with outer

Table 1. Morphometrics of Galeocharax goeldii. Standard length is expressed in $\mathrm{mm}$; measurements trough head length are percentages of standard length; the last four entries are percentages of head length. All specimens are from the rio Madeira basin, ANSP 39308 (holotype), UNIR 0008 and MZUSP 92432-36.

\begin{tabular}{lccccc}
\hline & Holotype & $\mathrm{n}$ & Range & Mean & SD \\
\hline Standard length & 44.3 & 22 & $25.7-123.0$ & 52.0 & \\
Depth at dorsal-fin origin & 30.2 & 21 & $25.8-31.0$ & 28.7 & 1.5 \\
Snout to dorsal-fin origin & 52.8 & 22 & $48.2-54.0$ & 50.3 & 1.5 \\
Snout to pectoral-fin origin & 32.0 & 22 & $28.4-33.7$ & 31.7 & 1.2 \\
Snout to pelvic-fin origin & 43.1 & 22 & $42.5-47.6$ & 44.7 & 1.7 \\
Snout to anal-fin origin & 54.8 & 22 & $53.5-58.0$ & 56.1 & 1.3 \\
Caudal peduncle depth & 8.1 & 22 & $7.4-8.9$ & 8.2 & 0.3 \\
Caudal peduncle length & 9.0 & 22 & $9.0-10.1$ & 9.5 & 0.3 \\
Pectoral-fin length & 15.8 & 18 & $13.8-17.4$ & 15.1 & 1.2 \\
Pelvic-fin length & 16.0 & 22 & $13.0-16.1$ & 14.2 & 0.9 \\
Dorsal-fin base length & 12.8 & 22 & $10.3-13.1$ & 12.0 & 0.7 \\
Dorsal-fin height & 29.5 & 22 & $26.4-29.8$ & 27.6 & 0.9 \\
Anal-fin base length & 37.9 & 22 & $33.7-38.7$ & 36.5 & 1.5 \\
Anal-fin lobe length & 20.3 & 22 & $15.0-20.6$ & 17.5 & 1.6 \\
Eye to dorsal-fin origin & 34.3 & 22 & $32.4-35.8$ & 34.3 & 1.1 \\
Dorsal-fin origin to & 48.7 & 22 & $47.8-52.7$ & 50.3 & 1.3 \\
$\quad$ caudal-fin base & 33.8 & 22 & $31.0-34.5$ & 32.5 & 0.8 \\
Bony head length & 28.6 & 22 & $23.7-30.0$ & 27.8 & 1.9 \\
Horizontal eye diameter & 30.6 & 22 & $29.1-32.9$ & 31.1 & 0.8 \\
Snout length & 21.3 & 22 & $21.1-23.6$ & 22.2 & 0.7 \\
Least interorbital width & 63.3 & 22 & $61.1-64.8$ & 63.1 & 1.1 \\
Upper jaw length & & & & & \\
\hline
\end{tabular}




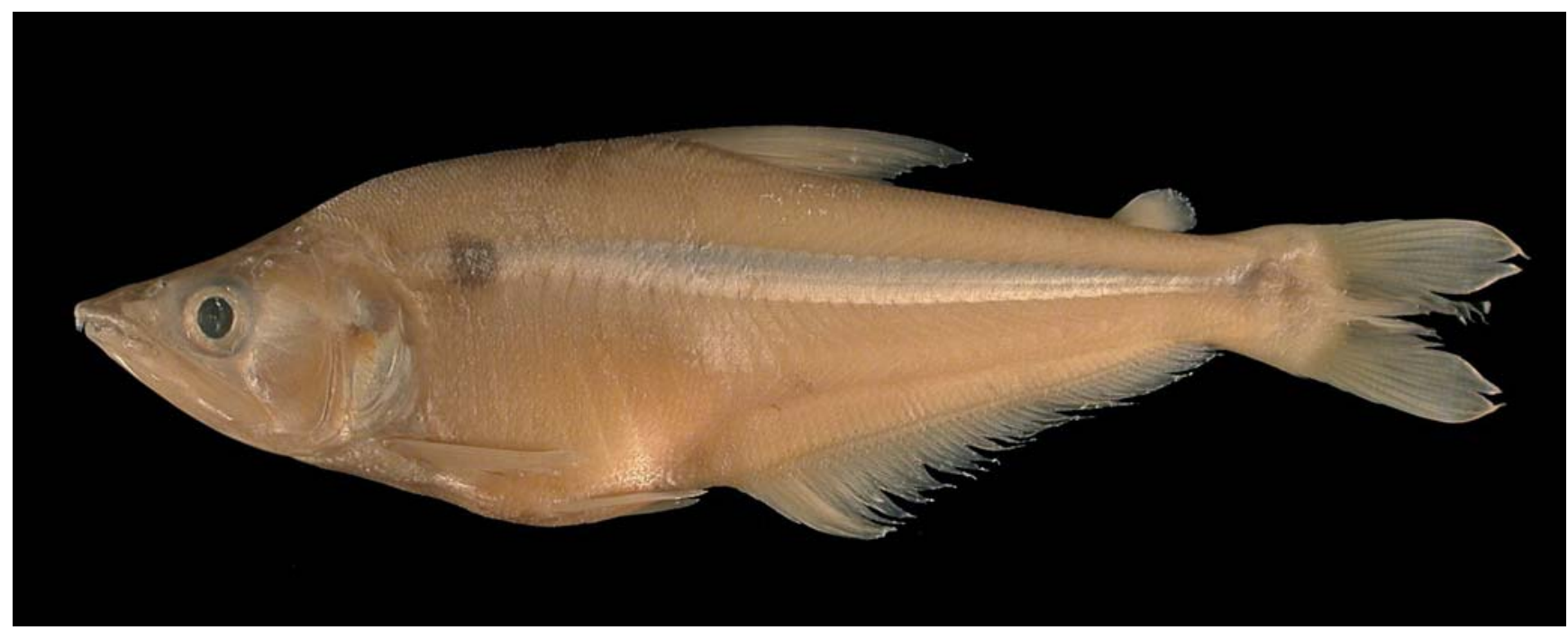

Fig. 2. Galeocharax goeldii, UNIR 0008, 123 mm SL, igarapé do Arara, rio Madeira, Porto Velho, Rondônia.

row of conical teeth which 4 anteriormost spaced and first, third and fourth larger than second, these followed by posterior row of 15-31 (18), 20.1, close-set conical teeth that show tendency to increase in number according to increase in standard length (Fig. 3). An inner row of 7-11 (7), 9 conical dentary teeth.

Vertebrae 41-43 (42), 41.8. Number of gill-rakers on upper limb of first gill-arch 2 in all specimens. Number of gill-rakers on lower limb of first gill-arch 6-7 (6), 6.2.

Color in alcohol. Body pale to light yellow, slightly darker dorsally than ventrally due to presence of dark chromatophores mostly concentrated along free border of scales. Dorsal part of head from tip of snout to supraoccipital region darker than remaining part of head. Faint dark stripe from tip of supraoccipital spine backward not quite reaching dorsalfin origin. Faint dark small blotch at dorsal-fin origin. Lateral dark body stripe extending from upper opercle to caudal-fin base where it connects to irregular dark blotch posteriorly extending to anterior part of middle caudal-fin rays. Lateral body stripe narrower from dorsal-fin origin anteriorly to upper opercle and on caudal peduncle, broader from below dorsal-fin origin to below adipose fin, sometimes obscured by guanine. Irregularly shaped dark blotch in humeral region over anterior lateral body stripe, vertically above pectoral fin. Anterior part of lower jaw bordered with dark pigmentation along bases of four anterior large conical teeth. Premaxilla and anterior maxilla pigmented with dark. Patch of dark chromatophores on lower half of opercle. All fins hyaline.

\section{Discussion}

Fowler (1950: 311) considered Charax goeldii as belonging to the genus Cyrtocharax Fowler and Schultz (1950: 62) and included it in the synonymy of Cyrtocharax amazonus (Günther), but Géry \& Vu-Tân-Tuê (1963: 240) suggested it should be allocated in Acestrocephalus Eigenmann, a sepa-

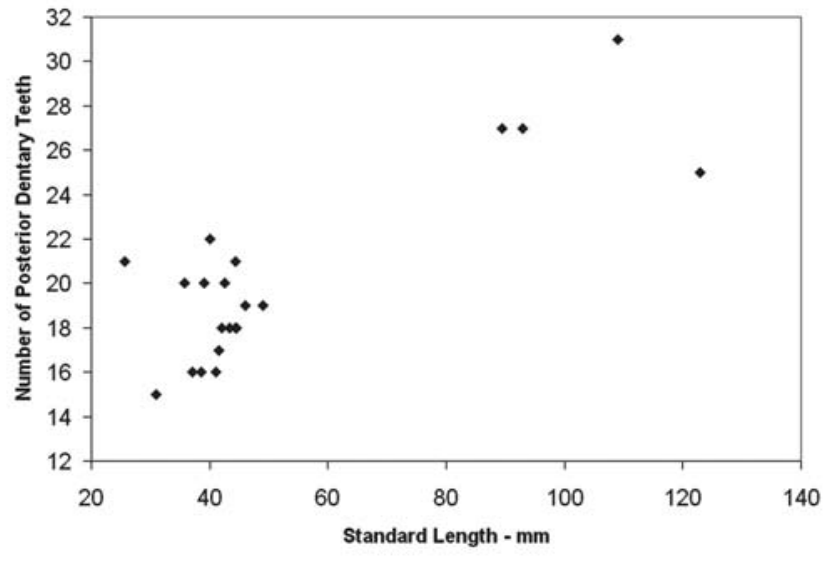

Fig. 3. Scatter plot of number of posterior dentary teeth on standard length for all examined specimens of Galeocharax goeldii.

rate subgenus of Cynopotamus Valenciennes together with C. gulo and C. humeralis. Menezes (1976) in reviewing Acestrocephalus, Galeocharax and Cynopotamus demonstrated that Cyrtocharax is a synonym of Cynopotamus, and proposed that $C$. gulo and $C$. humeralis should be included in Galeocharax, and Charax goeldii in the synonymy of Galeocharax gulo.

In the present study, examination of the type specimen and of specimens recently collected in the rio Madeira very close to the type locality indicated that Charax goeldii has all the characters used by Menezes (1976: 40-41) to define Galeocharax, including the absence of the ectopterygoid ventral crest, but that it is distinct from the other three species included in this genus (see Diagnosis).

The relative position of the dorsal-fin origin with respect to anal-fin origin emphasized by Géry (1972: 28) as a possible difference between G. gulo (anal-fin origin vertically far behind dorsal-fin origin) and G. goeldii (anal-fin vertically close to dorsal-fin origin) is not really significant. Even though in the poorly preserved type specimen of the latter species (Fig. 
1) the origin of the dorsal fin looks vertically closer to the origin of the anal fin, Fowler's original drawing, based on the recently collected type specimen (1913: 569) clearly shows that the anal-fin origin is approximately located vertically below the midbase of the dorsal fin as in G. gulo.

Galeocharax goeldii is known so far only from the rio Madeira basin. Galeocharax knerii (Steindachner) is found in the upper Paraná, G. humeralis in the Paraguay and lower Paraná, and G. gulo in the Amazon and Tocantins-Araguaia basins. Menezes (1976: 44-45) recorded G. gulo also in the rio São Francisco based on two lots (MZUSP 10586-87 - 2 specimens and MZUSP 1919 - 1 specimen) supposedly from Pirapora, Minas Gerais, but this record has not been confirmed. These specimens are part of the material that was sent on loan to the California Academy of Sciences in 1930 and when returned received, by mistake, catalog numbers different from the original ones. Part of what happened is explained by Britski (1969). It is absolutely certain that the specimens were not collected in the localities mentioned on the labels inside the jars corresponding to the above mentioned lots. No specimens of Galeocharax gulo have been recently collected or even reported from the rio São Francisco.

\section{Acknowledegments}

I am grateful to Carolina Doria (UNIR) who made possible the examination of the specimens collected by Gislene T. Vilara (Programa BADPI, Instituto Nacional de Pesquisas da Amazônia - INPA) during the survey in rio Madeira supported by Fundação Rio Madeira - RIOMAR/UNIR/FURNAS.

For the loan of the holotype of Galeocharax goeldii I thank Mark Sabaj (ANSP). Sandra J. Raredon (National Museum of Natural History, Smithsonian Institution, USA) photographed and radiographed the holotype. Eduardo G. Baena (MZUSP) provided a photograph of one of the specimens deposited at MZUSP and computer assistance. José Lima de Figueiredo (MZUSP) read the manuscript and made useful comments. The author is partially supported by a grant from CNPq (process 300101-03-1).

\section{Literature Cited}

Böhlke, E. B. 1984. Catalog of type specimens in the ichthyological collection of the Academy of Natural Sciences of Philadelphia. Special Publication, 14: 1-246.

Britski, H. A. 1969. Lista dos tipos de peixes das coleções do Departamento de Zoologia da Secretaria da Agricultura de São Paulo. Papéis Avulsos de Zoologia, São Paulo, 22(19): 197215.

Eschmeyer, W. N. (ed.). 1998. Catalog of Fishes. California Academy of Sciences, San Francisco, 2905 p.

Fink, W. L. \& S. H. Weitzman. 1974. The so-called cheirodontin fishes of Central America with description of two new species (Pisces: Characidae). Smithsonian Contributions to Zoology, 172: 1-46.

Fowler, H.W. 1913. Fishes of the Madeira River, Brazil. Proceedings of the Academy of Natural Sciences of Philadelphia 65(3): 517 579.

Fowler, H.W. 1950. Os peixes de água doce do Brasil (2 $2^{\mathrm{a}}$ entrega). Arquivos de Zoologia, São Paulo, 6: 205-404.

Géry, J. 1972. Corrected and suplemented descriptions of certain characoid fishes described by Henry W. Fowler, with revisions of several of their genera. Studies on Neotropical Fauna and Environments, 7: 1-35.

Géry, J. \& Vu-Tân-Tuê. 1963. Définitions de Cynopotamus Val. et genres voisins (Pisces, Characoidei) (Suite). III. Définitions et clés dés genres et des espèces. Bulletin du Muséum National d'Histoire Naturelle (2)35(3): 283-243.

Lucena, C. A. S. \& N. A. Menezes. 2003. Subfamily Characinae. Pp. 200-208. In: R. E. Reis, S. O. Kullander \& C. J. Ferraris (eds.). Check list of freshwater fishes of South and Central America. Edipucrs, Porto Alegre, 729 p.

Menezes, N. A. 1976. On the Cynopotaminae, a new subfamily of the Characidae (Osteichthyes, Ostariophysi, Characoidei). Arquivos de Zoologia, São Paulo, 28(10): 1-91.

Menezes, N.A. 2006. Description of five new species of Acestrocephalus Eigenmann and redescription of $A$. sardine and A. boehlkei (Characiformes: Characidae). Neotropical Ichthyology, 4(4): 385-400.

Schultz, L. P. 1950. Review of thirteen genera of South American Fishes in the subfamilies Cynodontinae, Hepsetinae, and Characinae, with descriptions of a new Cyrtocharax. Studies honoring Trevor Kincaid. Seattle, Washington: 44-73.

Received December 2006 Accepted February 2007 